\title{
Evaluation of Isolates of Rhyzoctonia Solani \& Fusarium Oxysporum on Sugar Beet under Field Conditions
}

\author{
Krasimira Tanova*, Svilen Raykov \\ "Episkop Konstantin Preslavski University of Shumen, Shumen \\ *k_tanova@abv.bg
}

\section{INTRODUCTION}

Root decay during the sugar beet vegetation appears periodically in the area of distribution of this culture and the most common consequences of this are greatly lowered productivity and quality, which is an economic risk to the industry (Tanova, 2003). Diseases of the root system of the crop, incl. the roots of beet are from ecological-microbial type. They are considered as a pathological syndrome, a combination of several pathogen and the most common are soil-dwelling microorganisms possessing the necessary pathological activity (Naidenov and Nechev, 2001).

Therefore, the etiology of root decay is specific and complex. According to Tanova (2003), root decay in sugar beet is caused by a complex microorganisms, and most aggressive pathogen determines the type of root decay. According to some authors the types of soil fungi of the genus Fusarium attack beet before the formation of root, but the symptoms occur in a particular combination of favorable factors for each type of media (Toporovskaia ,1985).

Fusarium decay is expressed in the tail decay from the central strand and is well expressed mikotraheozis. Most frequently from diseased plants are isolated species of Fusarium oxysporum (Bouchot, 1983) and the disease is provoked strong with moderate humidity and temperatures 22$30^{\circ} \mathrm{C}$. Fungi of the genus Fusarium infect plants earlier, before the formation of root and under favorable conditions the disease continues as an object of attack are roots, which form cavities filled with dense white to pink mycelium (Alhovskaya and Zagursky, 1985).

In a dry and hot climate, the soil pathogen Rhyzoctonia solani predominants in the complex of root decay of sugar beet (Tanova and Raykov, 2008). Usually complex causes of root decay in beet root system damage and other crops from beet crop rotation, which creates favorable conditions for the accumulation of contamination in the soil. Umralina and others. (1987) found differences in cultures and aggressiveness of Rhizoctonia solani isolated from sugar beet and conditionally divide them into two groups as defined anastomosis affiliation.

As regards the causative Fusarium oxysporum some differences in the aggressiveness of the resulting isolates are ascertained (Dayakov, 1993 ). It is well known that the interaction of the host plant and the pathogen occurs changes in the chemical composition and ferment system. The activity of the oxidase enzymes - catalase, peroxidase and polyphenol oxidase in diseased plant is changed depending on the aggressiveness of the pathogen and in practice are associated with the resistance of the plant (Christova, 1980).

The aim of this study is to test the aggressiveness of the isolates from Rhyzoctonia solani Kuhn and Fusarium oxysporum, obtained from sugar beet and establish their influence on the chemical composition and production of oxidase enzymes in a sick root.

\section{MATERIAL AND METHODS}

The study is conducted at the Laboratory of Phytopathology of Shumen University, the experiment field and beet technological laboratory of the Institute of Agriculture - the city of Shumen in 20142015 г. Five isolates were used: 3 of Rhizoctonia solani Kuhn and 2 isolates of Fusarium oxysporum. Inoculation was made under field conditions in parallel by two methods: individually, by placing a 
block of agar culture pathogens at the head of root crop (Schnaider, 1983) and by infected meal of beet seeds buried at about $4-5 \mathrm{~cm}$ of root crop $\left(150-200 \mathrm{~g} / \mathrm{m}^{2}\right)$. The infection was made in the middle of July in an area of $2 \mathrm{~m}^{2}$ of each isolate in 4 repetitions. The degree of attack was calculated on 5 grade scale (Tanova, 2003). The aggressiveness of the pathogen was calculated as \% diseased roots / $\mathrm{m}^{2}$, during the vegetation and at harvest. To determine the activity of the enzymes peroxidase and polyphenoloxidase (defining the plant reaction to environmental conditions), pectinase and invertase (related to the production of sugar) modifications of known methods were used (Boyarkin, 1951; Boyarkin, 1954; Sapozhnikova, 1981; Helemskii et al., 1977). The sucrose content, mineral nonsugars, reducing substances and amino nitrogen was recorded in hot water extracts clarified with lead acetate (Bozhkov, 1972; Christova, 1980). The technological parameters; white sugar yield per unit of production and purity of heavy juice was calculated from the content of sucrose and non-sugar (Christova, 1980). Data on the chemical composition are presented as\% to the average mass of beet (\% smts).The analyses were performed immediately after the removal of samples contaminated with infected flour.

\section{RESULTS AND DISCUSSION}

The results for the aggressiveness of the isolates tested in two methods of field inoculation are presented in Table 1.

Table1. Aggressiveness of Rhizoctonia solani and Fusarium oxysporum isolates after field inoculation of sugar beet

\begin{tabular}{|c|c|c|c|c|c|c|c|c|}
\hline \multirow[b]{2}{*}{ Isolates } & \multicolumn{4}{|c|}{$\begin{array}{c}\text { Inoculation with agar-block } \\
\% \text { diseased plants } / \mathrm{m}^{2}\end{array}$} & \multicolumn{4}{|c|}{$\begin{array}{c}\text { Inoculation with infected powder } \\
\% \text { diseased plants } / \mathrm{m}^{2}\end{array}$} \\
\hline & $\begin{array}{c}\text { I } \\
\text { term of } \\
\text { reading }\end{array}$ & $\begin{array}{c}\text { II } \\
\text { term of } \\
\text { readin } \\
\quad \mathrm{g}\end{array}$ & $\begin{array}{c}\text { III } \\
\text { term of } \\
\text { readin } \\
\mathrm{g}\end{array}$ & $\begin{array}{c}\text { IV } \\
\text { term of } \\
\text { reading }\end{array}$ & $\begin{array}{l}\text { I } \\
\text { term of } \\
\text { readin } \\
\mathrm{g}\end{array}$ & $\begin{array}{l}\text { II } \\
\text { term of } \\
\text { readin } \\
\quad \mathrm{g}\end{array}$ & $\begin{array}{l}\text { III } \\
\text { term of } \\
\text { readin } \\
\mathrm{g}\end{array}$ & $\begin{array}{l}\text { IV } \\
\text { term } \\
\text { of } \\
\text { readi } \\
\text { ng }\end{array}$ \\
\hline $\mathbf{R}_{1}-$ Rhizoctonia solani & 3.9 & 9.0 & 17.0 & 19.3 & 5.0 & 14.0 & 18.9 & 22.4 \\
\hline $\mathbf{R}_{2-}$ Rhizoctoniasolani & 8.7 & 14.7 & 20.9 & 20.0 & 9.0 & 13.0 & 18.5 & 24.0 \\
\hline $\mathbf{R}_{3^{-}}$Rhizoctonia solani & 10.2 & 17.4 & 34.0 & 32.0 & 15.2 & 25.9 & 20.3 & 35.0 \\
\hline F $_{1}$ Fusariumoxysporum & 3.0 & 3.4 & 12.5 & 17.5 & 12.5 & 11.9 & 14.3 & 21.7 \\
\hline $\mathrm{F}_{2-}$ Fusariuoxysporum & 2.5 & 6.5 & 8.9 & 9.2 & 6.8 & 4.0 & 6.0 & 11.3 \\
\hline Control & 1.7 & 1.5 & 3.2 & 5.8 & 1.7 & 1.5 & 3.2 & 5.8 \\
\hline
\end{tabular}

The results in the Table show differences in the aggressiveness of all tested isolates. Isolates of Rhizoctonia solani Kuhn, regardless of the method of infection and the time of recording showed more expressed aggressiveness than those of these of Fusarium oxysporum. In inoculation using the method of Schnaider (1983), with agar block at the beginning of the reporting period the highest \% diseased plants $/ \mathrm{m}^{2}$ is reported for isolate $\mathrm{R}_{3}$ of Rhizoctonia solani- $10.2 \%$, and the lowest for isolate $\mathrm{F}_{2}$ of Fusarium oxysporum- $2.5 \%$.

This trend continued throughout the study period, as the last reporting - extractions beet for isolate $\mathrm{R}_{3}$ of Rhizoctonia solani are reported $32 \%$ diseased plants $/ \mathrm{m}^{2}$, and for isolate $\mathrm{F}_{2}$ of Fusarium oxysporum- 9.2\%. Reporting in inoculated plants in our method with infected flour show the same trend for higher aggressiveness of isolate $\mathrm{R}_{3}$ of Rhizoctonia solani and lowest for isolate $\mathrm{F}_{2}$ of Fusarium oxysporum.

This trend exists for the entire period of the study while in pulling the beet is found that for isolate $\mathrm{R}_{3}$ $\%$ diseased plants $/ \mathrm{m}^{2}$ are 35 , but for isolate $\mathrm{F}_{2}-11.3$. The comparison in performance between two methods shows a trend in favour of inoculation with infected flour. The results of this test show that tested isolates differ in aggressiveness. Isolates tested of Rhizoctonia solani are more aggressive that those related to Fusarium oxysporum. Most aggressive isolate is $\mathrm{R}_{3}$ of Rhizoctonia solani, and poorest - isolate $\mathrm{F}_{2}$ of Fusarium oxysporum.

Table 2 presents the results of the chemical analysis of the experimental options. 
Table2. Influence of different isolates of Rhizoctonia solani and Fusarium oxysporum on the chemical structure and some technological indices of sugar beet (relative values)

\begin{tabular}{|c|c|c|c|c|c|c|c|}
\hline \multirow{2}{*}{ Isolates } & \multirow{2}{*}{$\begin{array}{c}\text { Sucrose } \\
\% \% \\
\text { aAccordi } \\
\text { ng to K }\end{array}$} & \multicolumn{6}{|c|}{ Nonsugars, $\%$ of dry mass $-\%$ according to $K$} \\
\hline & & $\mathbf{K}$ & $\mathbf{N a}$ & $\begin{array}{l}\text { amino- } \\
\text { nitrogen }\end{array}$ & $\begin{array}{l}\text { Reducing } \\
\text { Substance }\end{array}$ & $\begin{array}{l}\text { juice } \\
\text { purity }\end{array}$ & output \\
\hline $\mathbf{R}_{1-}$ Rhizoctonia solani & $83.4^{00}$ & 89.2 & 105.4 & 105.4 & $198.7^{+++}$ & $94.7^{00}$ & $68.9^{000}$ \\
\hline $\mathbf{R}_{2-}$ Rhizoctonia solani & 92.4 & 87.4 & 106.7 & 113.8 & $162.2^{+++}$ & $94.8^{00}$ & $79.3^{00}$ \\
\hline $\mathbf{R}_{3^{-}}$Rhizoctonia solani & 78.2.00 & 98.8 & 130.3 & 105.4 & $144.8^{+++}$ & $91.1^{000}$ & $83.7^{0}$ \\
\hline F $_{1}$ - Fusarium oxysporum & 100.0 & 93.0 & 88.5 & 112.5 & $134.3^{++}$ & 99.9 & 101.1 \\
\hline $\mathrm{F}_{2-}$ Fusarium oxysporum & 95.0 & 91.7 & 96.2 & 108.0 & $1^{127.9} .^{++}$ & 99.3 & 94.4 \\
\hline Control & 100 & 100 & 100 & 100 & 100 & 100 & 100 \\
\hline Control value & 15.9 & 3.71 & 2.75 & 5.33 & 0.105 & 88.8 & 12.6 \\
\hline GD - 5\% & 9.0 & 24.9 & 40.5 & 28.0 & $\mathbf{1 8 . 5}$ & 3.4 & 13.2 \\
\hline GD - 1\% & 12.8 & 35.4 & 57.2 & 39.8 & 26.3 & 4.8 & 18.8 \\
\hline GD $-0.1 \%$ & 18.5 & 51.2 & 83.3 & 57.6 & 38.1 & 6.9 & 27.2 \\
\hline
\end{tabular}

The results showed that the infected roots have altered chemical composition, depending on type of pathogen and the aggressiveness of the isolates thereof. The indicator sugar content measured in \% deteriorates in Rhizoctonia solani isolates, as in strongest degree thus applies for isolate $\mathrm{R}_{3}$ of this pathogen.

Isolates of Rhizoctonia solani- $\mathrm{R}_{1}, \mathrm{R}_{2}$ и $\mathrm{R}_{3}$ increase significantly the quantity of reducing substances, highly lowering the purity of the juice and the yield of the sugar, wherein the infected roots are completely unsuitable for processing and the production of sugar. Isolates of species Fusarium oxysporum- $\mathrm{F}_{1}$ and $\mathrm{F}_{2}$ show trend to reduce the amount of sugar in infected roots, but they also reduce the quality of the product because it was established they highly increase the amount of reducing agents which is undesirable in sugar production.

The results of chemical analyses show that the studied isolates of Rhizoctonia root decay Rhizoctonia solani Kuhn and Fusarium wilting and decay of root - Fusarium oxysporum strongly worsen the raw material of sugar beet and make it unsuitable for sugar production (Christova, 1980).

Table 3 presents the results of analyses of oxidase enzymes in the infected roots.

Table3. Influence of different Rh. solani isolates and F.oxysporum isolates of the activity of some ferments in the sugar beet roots

\begin{tabular}{|l|l|l|l|}
\hline Isolates tested & Peroxidase & Polifenoloxidase & Invertase \\
\hline $\mathbf{R}_{\mathbf{1}}$ - Rh. solani & $\mathbf{3 . 9 0}^{++}$ & 2.86 & $\mathbf{3 5 . 8 2}^{+++}$ \\
\hline $\mathbf{R}_{2}$ - Rh. solani & $\mathbf{4 . 3 8}^{++}$ & 2.89 & $\mathbf{2 1 , 0 4}^{+++}$ \\
\hline $\mathbf{R}_{\mathbf{3}^{-}}$Rh. solani & $\mathbf{3 . 5 5}^{++}$ & 2.82 & $\mathbf{1 6 . 5 2}^{++}$ \\
\hline F F.oxysporum & 2.17 & 2.87 & 4.80 \\
\hline F $_{\mathbf{2}}$ F.oxysporum & 2.12 & 2.88 & 5.97 \\
\hline Control & 1.60 & 2.88 & 2.13 \\
\hline GD- 5\% & 1.36 & 0.12 & 7.44 \\
\hline GD- 1\% & 1.93 & 0.17 & 10.58 \\
\hline
\end{tabular}

Note: The ferments are shown as activity:

Peroxidase - ferment's activity as change of the optical density for $1 \mathrm{sec}$ from $1 \mathrm{~g}$ fresh sample;

Polifenoloxidase - activity of the ferment as mmol oxidation for $1 \mathrm{~min}$ from $1 \mathrm{~g}$ fresh sample of ascor bic acid;

Invertase - activity of the ferment as mmol invertive sugar, formed for $1 \mathrm{~min}$ from $1 \mathrm{~g}$ fresh sample.

The interaction pathogen / host induces changes in the activity of some enzymes. Under the influence of isolates of $R h$. solani $-\mathrm{R}_{1}, \mathrm{R}_{2}$ and $\mathrm{R}_{3}$ reliably increases peroxidase and invertase activity, while that of polyphenoloxidase is on the level of control for all tested isolates (Table 3). Isolates of F.oxysporum do not cause chamge in the oxidase enzymes of infected roots. Slight increasing of pectinase activity, up to $10 \%$ was found only in isolate $\mathrm{R}_{3}$. 
Increasing the peroxidase and invertase activity to a significant level corresponds to decreasing in sugar content and increasing the reducing substances in roots. This leads to decreasing in both - yield of white sugar, and the purity of the juice.

Increasing pectinase activity suggests increasing of soluble pectin in beet (Хелемский et al., 1977), which together with reducing agents causes significant difficulties in beet processing. Data on chemical composition and activity of enzymes studied give reason to make some differentiation of isolates tested.

\section{Conclusions}

Tested isolates differ in aggressiveness as highly aggressive are isolates of Rhizoctonia solani Kuhn, and less aggressive are isolates of Fusarium oxysporum.

Isolates of Rhizoctonia solani Kuhn are arranged in aggressiveness in the following descending order: $\mathrm{R}_{3} ; \mathrm{R}_{2}$ and $\mathrm{R}_{1}$, and isolates of Fusarium oxysporum- $\mathrm{F}_{2}$ and $\mathrm{F}_{1}$.

Isolates of Rhizoctonia solani Kuhn worsen technological qualities of infected roots and raise their peroxidase and invertase activity.

Isolates of Fusarium oxysporum worsen in weaker level technological qualities of infected roots and do not affect the fermented activity.

\section{REFERENCES}

[1] Alhovskaya, TF, A.B.Zagursky. 1985. Effektivn1e mer1 zaschit1 MAR. svekl1 from disease when it vozdelivaniya Industrialna tehsnologii. 32-37.

[2] Bouchot D, 1983.L analyse sanitaire des betrawes . $23^{\text {eme }}$ colloquy SFP.Versailles. 21-23.10./ Les colloques de INKH.,Vol.4. 35-42.

[3] Boyarkin A N, 1951. Biochemistry., № 4

[4] Boyarkin, AN. 1954. T.rudı Institute of Plant Physiology. Timiryazev Academy of Sciences of the USSR, 8, № 2. 398- 403

[5] Bozhkov, L. 1972. Himikotehnologichen control during production in the male

[6] Christova, L. 1980. - Scientific papers. Institute zaharodobiv - Gorna Oryahovitsa, 15-24, t.Z,

[7] Helemskii, MZ, M.L.Peltts, I.R.Sapozhnikova. 1977.Biochemistry in sugar beet production.

[8] Dayakov, YU.T. 1993,- Mycology and Phytopathology, ie. 27, № 6, 72-82 with

[9] Naidenov M., Nechev G. 2001. Is it possible biological control of soil patogens .Plant protection. Vol. 2. 23-28.

[10] Tanova K., 2003. Abstract of his doctoral thesis. Sofia. 56.

[11] Tanova K. Raykov S. 2008._ Development of Rhyzoctonia root rot in beet artificial infectious background. Yearbook "Bishop. Preslavski "t. XVIII B3, Shumen 2008, p. 23-30.

[12] Toporovskaia J.1985. Dynamics of the population of fungi sugar beet. Mycology and Phytopathology. T.5.v.1.50-56.

[13] Sapozhnikova, EV1981. Pektinovie fruit substance, 181.

[14] Schneider, G.L., H.S. Poter. 1983 .Journal of the American society of sugar beet technologists, 22, 54-53 p.

[15] Umralina, AP, NV Vasilyev, T.V.Kachan, 1987. Mycology and Phytopathology, vol. 21, number 3 